NBER WORKING PAPER SERIES

\title{
HOW DO BANKS MANAGE LIQUIDITY RISK? EVIDENCE FROM EQUITY AND DEPOSIT MARKETS \\ IN THE FALL OF 1998
}

\author{
Evan Gatev \\ Til Schuermann \\ Philip E. Strahan \\ Working Paper 10982 \\ http://www.nber.org/papers/w10982 \\ NATIONAL BUREAU OF ECONOMIC RESEARCH \\ 1050 Massachusetts Avenue \\ Cambridge, MA 02138
}

December 2004

\begin{abstract}
We would like to thank Brian Madigan and participants at the NBER conference on "Risks of Financial Institutions," Oct. 2004 (Woodstock, VT) for their comments, Gretchen Weinbach for help with the data and Kristin Wilson for her excellent research assistance. All errors are ours. Any views expressed represent those of the authors only and not necessarily those of the Federal Reserve Bank of New York or the Federal Reserve System. The views expressed herein are those of the author(s) and do not necessarily reflect the views of the National Bureau of Economic Research.

(C) 2004 by Evan Gatev, Til Schuermann, and Philip E. Strahan. All rights reserved. Short sections of text, not to exceed two paragraphs, may be quoted without explicit permission provided that full credit, including (C) notice, is given to the source.
\end{abstract}


How do Banks Manage Liquidity Risk? Evidence from Equity and Deposit Markets in the Fall of 1998

Evan Gatev, Til Schuermann, and Philip E. Strahan

NBER Working Paper No. 10982

December 2004

JEL No. G18, G21

\title{
ABSTRACT
}

We report evidence from the equity market that unused loan commitments expose banks to systematic liquidity risk, especially during crises such as the one observed in the fall of 1998 . We also find, however, that banks with higher levels of transactions deposits had lower risk during the 1998 crisis than other banks. These banks experienced large inflows of funds just as they were needed -- when liquidity demanded by firms taking down funds from commercial paper backup lines of credit peaked. Our evidence suggests that combining loan commitments with deposits mitigates liquidity risk, and that this deposit-lending synergy is especially powerful during period of crises as nervous investors move funds into their banks.

\author{
Evan Gatev \\ Boston College \\ evan.gatev@bc.edu \\ Til Schuermann \\ Federal Reserve Bank of New York \\ Philip E. Strahan \\ Carroll School of Management \\ 324B Fulton Hall \\ Boston College \\ Chestnut Hill, MA 02467 \\ and NBER \\ philip.strahan@bc.edu
}




\section{Introduction}

The rise of the commercial paper market and the subsequent growth of the junk bond market in the 1980s and 1990s have seemingly reduced the role of banks in the financing of large businesses (Mishkin and Strahan, 1998). This much-remarked-upon evolution away from banks and toward the securities markets has not rendered banks irrelevant (Boyd and Gertler, 1994). While they do provide less funding than before, banks remain important to large firms as providers of liquidity support to the commercial paper market. Banks act as the "liquidity provider of last resort" by promising to offer cash on demand through commercial paper backup lines of credit. ${ }^{3}$ This liquidity insurance role became especially notable in the fall of 1998 , when many firms turned to their banks to provide liquidity normally supplied by the commercial paper market. During this episode, banks faced a systematic increase in the demand for liquidity. This paper studies how banks were able to manage this systematic liquidity risk and thus weather the 1998 crisis successfully.

Banks have traditionally provided liquidity, not only to borrowers with open lines of credit and loan commitments (we use these terms interchangeably), but also to depositors in the form of checking and other transactions accounts. Both contracts allow customers to receive liquidity (cash) on short notice. In fact, a financial intermediary combining these two products offers a reasonable definition of what most scholars and regulators mean by "bank." This liquidity insurance role exposes banks to the risk that they will have insufficient cash to meet

\footnotetext{
${ }^{3}$ Banks also continue to bear significant credit risk through off-balance sheet guarantees such as standby letters of credit.
} 
random demands from their depositors and borrowers. ${ }^{4}$

To the extent that liquidity demands are independent across customers, a bank can use scale to mitigate its need to hold cash to meet unexpected liquidity shocks. ${ }^{5}$ In fact, Kashyap, Rajan and Stein (2002) present a model in which a risk-management motive explains the combination of transactions deposits and loan commitments: as long as the demand for liquidity from depositors through the checking account is not highly correlated with liquidity demands from borrowers, an intermediary will be able to reduce its need to hold cash by serving both customers. Thus, their model yields a diversification synergy between demand deposits (or transactions deposits more generally) and loan commitments. As evidence, they show that banks offering more transaction deposits (as a percentage of total deposits) tend also to make more loan commitments (also scaled appropriately). The correlation is robust across all size categories of banks.

A bank offering liquidity insurance may face a problem if, rather than facing idiosyncratic demands for cash, it sometimes faces systematic increases in liquidity demand. For example, during the first week of October 1998, following the coordinated restructuring of the hedge fund Long Term Capital Management (LTCM), spreads between safe Treasury securities and risky commercial paper rose dramatically. Many large firms were unable to roll over their commercial paper as it came due, leading to a sharp reduction in the amount of commercial paper outstanding and a corresponding increase in take-downs on pre-existing lines of credit

\footnotetext{
${ }^{4}$ Liquidity risk has been used to justify government deposit insurance (e.g. Diamond and Dybvig, 1983).

${ }^{5}$ In a Modigliani-Miller world, holding cash is not costly. However, in a world with taxes, financial distress, or agency costs, holding cash or other liquid assets is costly for banks and other firms (e.g. Myers and Rajan, 1998).
} 
(Saidenberg and Strahan, 1999). ${ }^{6}$ As a result of this liquidity shock, banks faced a systematic spike in demand for cash because many of their largest customers wanted funds all at once. Because funding flowed into the banking system, however, this systematic increase in demand was easily met. Gatev and Strahan (2003) show that funding supply to banks moves inversely with market liquidity - that is, when commercial paper spreads widen, banks face a greater supply of funds (especially transactions deposits). Thus, when liquidity demands are at their highest, so is funding supply. Gatev and Strahan argued there that banks can weather a liquidity storm due to their perceived status as a safe haven for funds.

In this paper, we study the 1998 crisis to investigate differences across banks in their ability to manage systematic liquidity risk. We show that during the 1998 crisis, loan commitments exposed banks to liquidity risk, whereas transactions deposits insulated them from this risk. First, we report evidence from the equity market that transactions deposits reduce bank risk exposure, whereas unused loan commitments increase their exposure. We use stock return volatility observed during the three-month period beginning in the middle of August when the crisis began with the announcement of the Russian Default to measure risk. During this period, bank stock prices were buffeted by news of the Russian crisis, followed by the demise of the hedge fund LTCM in late September, and finally by the drying up of the commercial paper market in the first week of October. Banks with more unused loan commitments had higher risk, whereas those with more transactions deposits had lower risk. We compare this pattern with the three months prior to the Russian default, and show a much smaller correlation between risk and

\footnotetext{
${ }^{6}$ Commercial paper often has maturity as short as one week. Firms, however, routinely roll over their paper as it matures.
} 
either loan commitments or transactions deposits.

Second, we extend the Kashyap et al. and Gatev and Strahan results by exploring in greater detail how bank deposit growth responded to the 1998 liquidity crisis. We argue that the synergy between deposits and loan commitments emphasized by Kashyap et al. - that banks can reduce risk through diversification by holding demand deposits and loan commitments becomes especially powerful during crises because investors tend to move funds from the capital markets into their bank during these times. The conditional correlation between liquidity demanded from depositors and liquidity demanded by borrowers becomes negative during crises, thereby dramatically increasing the diversification benefit of combining these two products. This negative correlation shows up as an increase in funds flowing into bank transaction deposit accounts at the same time that funds are flowing out of the bank as borrowers take down funds from pre-existing lines of credit.

As evidence, we test how funding behaved during the first weeks of October 1998, when banks faced a dramatic increase in demand for funds from firms unable to roll over their commercial paper. This increase in liquidity demand obligated banks to supply funds because firms had established their commercial paper backup lines prior to the onset of the crisis. We find that banks with more transactions deposits as a share of total deposits (based on data just before the onset of the crisis) had much greater inflows of deposits, and that all of those inflows were concentrated among transactions deposits rather than other deposits. Banks with more unused loan commitments before the onset of the crisis also experienced increased growth of deposits, which reflected their greater demand for funds (resulting from take-down demand by their borrowers). We find that these relationships reversed sign at the end of October, as the 
commercial paper spreads fell and the market began to function as it normally does. That is, as the crisis subsided funds flowed out of bank transactions deposit accounts and, presumably, back into the capital markets.

Our results show that transactions deposits play a critically important role in allowing banks to manage their liquidity risk. The findings strengthen the Kashyap et al. theoretical argument, and they help explain the robust positive correlation across banks between transaction deposits and loan commitments.

The remainder of the paper proceeds as follows. Section II below provides some background by describing banks' liquidity insurance role in the commercial paper market, and describes the chronology of the 1998 crisis. The key issue for our test is finding the right week(s) when banks faced a systematic increase in liquidity demand. Section III then describes our data, empirical methods and results. Section IV concludes the paper.

\section{The 1998 Liquidity Crisis}

The focus of this paper is on how the banking system in the United States survived the dramatic decline in risky asset prices during the fall of 1998. The episode has been called a 'liquidity' crisis mainly because the widespread decline in asset prices did not seem to be fully

explainable based on cash-flow fundamentals. But for our purposes, these events did lead to a well-defined liquidity crisis in the commercial paper market because a large number of borrowers were unable to re-finance their paper as it matured. In response, many of these issuers turned to their bank for funds.

In our first set of results, we focus on bank stock return volatility during the whole three- 
month period, beginning when Russia defaulted (August 17) and ending after spreads in the commercial paper market returned to normal levels (November 17). As shown in Kho, Lee and Stulz (2000), bank stock prices were hit throughout this period by news about conditions in credit markets across the world. We do not model changes in the level of stock prices, which would require us to pinpoint exactly what events were viewed as harmful (e.g. Russia's default and subsequent deviation) or helpful (e.g. announcements that the IMF would intervene in Brazil). Instead, we focus on explaining how the cross-section of stock return volatility, measured throughout the whole three-month period, reflects exposure to liquidity risk as well as tools to manage that risk.

We then analyze the cross-section of deposit changes, focusing specifically on the oneweek period ending on October 5. While the whole three-month period following the Russian default did raise uncertainty for banks and bank stock prices (Figure 1), it was only during October that banks in fact faced a sharp increase in liquidity demands. Thus, while forwardlooking stock prices (and hence volatility) over the whole period reflected the effects of the liquidity crisis, bank balance sheets only reacted during the weeks when liquidity demand spiked.

Bad news began on August 17, 1998, when the Russian government announced its intention to default on its sovereign debt, floated the exchange rate, and devalued the Ruble (Chiodo and Owyang, 2002). The announcement was followed by a steep drop in U.S. equity prices during the last two weeks of August, and a sustained period of high volatility in asset markets across the world (Figure 1).

Outside of the U.S. equity market, the prices of risky debt securities across the whole 
credit spectrum and across markets began to fall sharply after Russia's announcement. For example, the spread between speculative grade and investment grade debt in the U.S. bond market rose from about 1.8 percentage points in mid-August to 2.5 percentage points by October. Spreads of risky bonds outside the U.S., as well as swap spreads, also widened dramatically (Saidenberg and Strahan, 1999).

Partly as a result of simultaneous collapse in the prices of risky assets across many markets, the hedge fund LTCM announced to its shareholders on September 2 that the fund had sustained large losses. These losses mounted as credit spreads continued to widen, moving well beyond levels that had been observed during the 1990s. LTCM was unable to secure additional investment from its owners or liquidity support from its creditors (Lowenstein, 2000). As a result, the hedge fund faced the possibility of an uncoordinated unwinding of its large positions in the bond and swaps markets. The Federal Reserve Bank of New York, fearing the potential systemic consequences of a rapid liquidation of LTCM's large positions in the face of already falling asset prices, brokered a private-sector restructuring of the fund. The news of the restructuring became public on Wednesday, September $23 .^{7}$

The effects of these events can be seen clearly in tracking bank stock prices over this period. Panel A of Figure 1 reports the change in an equally-weighted index of bank stock prices and the S\&P 500 from the middle of May, 1998 through the middle of November. Panel B reports the conditional volatility over the same period for this bank-stock index. ${ }^{8}$ Bank stock prices began to fall in the summer, and then dropped sharply after the Russian default on August

\footnotetext{
${ }^{7}$ See Edwards (1999) for an evaluation of the policy implications of the Fed's actions.
} 
17. Prices stabilized in September until the announcement of the restructuring of LTCM and the pull back in the commercial paper market, then fell sharply again. The conditional volatility of bank stocks also spiked just after the Russian default, stabilized in September, and spiked again in the beginning of October. Both the level and volatility of bank stock prices quickly recovered in the second half of October. While these patterns are also evident for the S\&P 500, the effects of the 1998 crisis appear larger for banks stocks, both in terms of price levels and return volatility. ${ }^{9}$

The U.S. commercial paper (CP) market also began to feel the effects of investor's pulling back from risky assets during the week following LTCM's collapse. Spreads on shortterm, high-grade $\mathrm{CP}$ over Treasury securities of comparable maturity had risen gradually throughout the end of August and throughout September, from about 55 basis points to about 70 basis points just prior to LTCM's demise. Spreads then jumped sharply, rising to more than 100 basis points and remaining at that level for the first three weeks of October (Figure 2). Spreads on low-grade commercial paper increased even more than spreads on high-grade paper. The jump in these spreads reflected rationing in the commercial paper market, as the stock of outstanding commercial paper declined by more than two percent during the month of October. ${ }^{10}$ Credit rationing places issuers in the position of facing a liquidity crisis as their paper comes

\footnotetext{
${ }^{8}$ The conditional volatility (standard deviation) is estimated from a GARCH $(1,1)$ model with a first-order autoregressive process for the mean (Nelson, 1991).

${ }^{9}$ Note that bank stock volatility was lower than the S\&P 500 before the crisis, but equal to or larger during the crisis.

${ }^{10}$ Stiglitz and Weiss (1981) show that equilibrium credit rationing is possible when borrowers are better informed than lenders.
} 
due. $^{11}$

At the same time that the $\mathrm{CP}$ market was drying up, growth in bank lending accelerated dramatically because the commercial paper issuers began to draw funds from their backup lines of credit. This growth in lending was concentrated at banks with high levels of undrawn loan commitments prior to the onset of the crisis. For example, among the top 50 banks, those with above-average levels of undrawn loan commitments (scaled by total loans plus commitments) saw lending rise three times as fast as banks with below-average undrawn loan commitments (Saidenberg and Strahan, 1999). Moreover, press reports suggest that most of the bank loan growth during the beginning of October occurred because of strong take-down demand by commercial paper issuers drawing funds from pre-existing credit lines, rather than because of new loan originations. The New York Times reported, for example, that "rather than signaling a flow of new loans, much of the lending appears to be borrowers' drawing on existing lines of credit (Uchitelle, 1998)." Thus, the liquidity crisis moved seamlessly from CP issuers to their banks. As we show next, banks with larger transaction deposits were better positioned to face this crisis: they experienced less volatility in their stock prices and, when the liquidity demands hit hardest, they experienced the greatest inflows of funds.

Expressing concern that "growing caution by lenders and unsettled conditions in financial markets more generally [were] likely to be restraining aggregate demand in the future," the

\footnotetext{
${ }^{11}$ Such crises had happened before 1998. Banks' role in offering liquidity insurance originated early in the development of the commercial paper market when the Penn Central Transportation Company defaulted on more than $\$ 80$ million in commercial paper outstanding. As a result of this default, investors lost confidence in other large commercial paper issuers, making it difficult for some of these firms to refinance their paper as it matured. The Federal Reserve responded to the Penn Central crisis by lending aggressively to banks through the discount window and encouraging them, in turn, to provide liquidity to their large borrowers (Kane, 1974). In response to
} 
Federal Reserve decreased the target Fed Funds rate by 25 basis points on October 15, 1998, to 4.75 percent. ${ }^{12}$ This was the first change in the Fed Funds rate since January 1996. The rate was dropped another 25 basis points on November17, 1998. It did not stay low for long, however, going back up to 5 percent in two steps by November 1999 .

\section{Empirical Methods, Data, and Results}

In this section, we report our results linking stock return volatility and changes in bank deposits to bank characteristics during the 1998 Crisis. We first describe our empirical methods, then our data, and last we report the results.

\section{A. Empirical Methods}

We test how pre-existing open lines of credit and pre-existing levels of transactions deposits affect both risk (stock returns) and deposit flows. Unused loan commitments expose banks to liquidity risk. Thus, we expect banks with more open credit lines to face greater liquidity risk (higher stock return volatility) and to face a greater demand for loans when the commercial paper market dried up in the beginning of October (faster deposit growth). Kashyap et al. argue that combining loan commitments with transactions deposits lowers risk due to diversification (because demands are less-than-perfectly correlated). This force is especially powerful during liquidity crises like the fall of 1998 because uninformed investors put funds into banks as a safe haven for their wealth. Thus, banks with more transactions deposits ought to have had lower risk than other banks, and they ought to have experienced faster growth of

this difficulty, commercial paper issuers thereafter began purchasing backup lines of credit from banks to insure against future funding disruptions. 
deposits when the CP market dried up in October.

To be more precise, we estimate two sets of cross-sectional regressions with the following structure:

(1) Stock Return Volatility ${ }_{i}=\alpha_{1}+\gamma_{1}$ Loan Commitment Ratio $_{i}+\gamma_{2}$ Transaction Deposit Ratio $_{i}$

+ Control Variables $i+\varepsilon_{1, i}$

(2) Deposit Change C $_{i}=\alpha_{2}+\beta_{1}$ Loan Commitment Ratio $_{i}+\beta_{2}$ Transaction Deposit Ratio $_{i}$

+ Control Variables ${ }_{i}+\varepsilon_{2, i}$

where $i$ refers to the bank. We estimate each of these regressions during the crisis period, and during a non-crisis period. For the crisis period, we expect the following: $\gamma_{1}>0$ and $\gamma_{2}<0$; $\beta_{1}>0$ and $\beta_{2}>0$. For equation 1 , we estimate a non-crisis period that ends in the middle of August; we expect similar qualitative results but much smaller magnitudes. For equation 2, we estimate the relationships during the weeks when the CP market dried up (crisis weeks), and again during the weeks when this market recovered. In this case, we would expect opposite relationships during the non-crisis period. Funds should flow into banks as the CP market dries up, and back out as it rebounds.

\section{B. Data}

$\underline{\text { Explanatory Variables }}$

To construct measures of liquidity risk exposure and transactions deposits, we follow the procedures outlined by Kashyap, Rajan and Stein (2002). We use the level of unused loan commitments as of June 1998 (that is, before the onset of the crisis), scaled by the sum of unused

\footnotetext{
${ }^{12}$ The announcement can be found at http://www.federalreserve.gov/boarddocs/press/general/1998/19981015/.
} 
loan commitments plus total on-balance sheet loans. ${ }^{13}$ This variable is our measure of a bank's potential exposure to a liquidity shock. We also report specifications where we replace the level of undrawn commitments by the change in undrawn commitments between June and December of 1998. Under the assumption that banks made no new loan commitments, this variable would represent the amount of loans actually taken down during the whole 6-month period; that is, the change in unused commitments would reflect the realization of liquidity demanded during the period. ${ }^{14}$ In our deposit flow regressions, these two variables can be thought of as alternative proxies included to control for the high level funds that a bank may need to meet the increased loan demand from $\mathrm{CP}$ issuers unable to roll over their paper.

To measure the size of a bank's transactions deposit base, we use total transactions deposits divided by total deposits. We take this variable from the Federal Reserve's FR2900 (Report of Transaction Accounts, Other Deposits, and Vault Cash) as of August 10, 1998, the last date prior to the onset of the crisis. The FR2900 provide confidential and detailed weekly data on bank deposits used to measure levels and changes in the money supply. ${ }^{15}$ Some of the deposit components are also used to calculate reserve requirements. Using a separate data source, Kashyap et al. show that transaction deposits are highly correlated with the loan commitment variable across banks, regardless of bank size. (Note that we also find a very strong

\footnotetext{
${ }^{13}$ We alter this definition slightly relative to what Kashyap et al. use by taking out unused loan commitments to retail customers (i.e. credit card lines). These retail exposures did not create liquidity problems for banks in the fall of 1998.

${ }^{14}$ Unfortunately, we know of no data that would allow us to observe the amount of funds taken down off of preexisting lines of credit, which would be the best measure of the shock to loan demand. Also, note that we are only able to observe bank loans and unused commitments at quarterly intervals. Since the crisis spans the end of the third quarter, we use the change in commitments from June to December.

${ }^{15}$ The confidential data were processed solely within the Federal Reserve for the analysis presented in this paper.
} 
positive correlation between transactions deposits and loan commitments in our data.) They do not, however, test whether transactions deposits in fact help banks hedge against the risks of a liquidity shock. That is, they do not measure the correlation of liquidity demands across these two classes of customers. This is the sense in which our approach extends and sharpens their empirical findings.

Our sample includes all domestic banking organizations with assets over $\$ 1$ billion (as of the June 1998 Call Report). We exclude the smaller banks because most of the commercial paper backup lines of credit are issued by large banks and, as we have said, the liquidity shock was driven by the absence of liquidity in the commercial paper market. Again following Kashyap et al., we aggregate the bank-level data from the June 1998 Call Report up to the level of the highest holding corporation. This aggregation takes account of the possibility that affiliated banks can pool their resources to hedge against unexpected liquidity shocks.

Beyond the two variables of interest, we also control for a series of additional bank characteristics, including the log of total assets, the capital-asset ratio, an indicator equal to one for banks with a credit rating, the ratio of liquid assets (cash plus securities) to total assets, the ratio of Fed Funds purchased to total assets, and an indicator equal to one if the bank's stock is publicly traded. We include bank size and capital to test whether risk or deposit inflows were affected by insolvency risk - larger and better capitalized banks are less likely to fail all else equal. Larger banks also may have been viewed as safer than smaller ones if the implicit government safety net is more generous for them. We control for asset liquidity for the obvious reason that banks with more liquid balance sheets will be better able to meet the demands of borrowers taking down funds from pre-existing loan commitments. Similarly, banks with greater 
access to the Fed Funds market may be better able to weather a liquidity shock. The publicly traded and rated indicators are included to test whether less opaque banks fared better during the crisis. Last, we include indicator variables equal to one for banks exposed to Russia and to LTCM (see Kho, Lee and Stulz, 2000).

$\underline{\text { Dependent Variables }}$

To measure bank risk, we use three months of daily stock return data from CRSP to construct the standard deviation of each bank's stock return from the onset of the crisis on August 17, 1998. We construct the same volatility measure during the three-month period ending on August 14 to construct a benchmark set of results to make sure that the relationships we observe during the fall really have something to do with the liquidity crisis, rather than some time invariant characteristics of banks.

For deposit flows, we construct the change in total deposits during the week ending on October 5, 1998. This first week of October follows the restructuring of LTCM at the end of September and was the critical week in which CP spreads first spiked (Figure 2). Spreads remained high for an additional two weeks, so we also report as a robustness test the change in deposits during the three-week period ending on October 19. Recall from Section II that the target Fed Funds rate was lowered on October 15, and lowered again on November 17. Thus, in contrast to our robustness tests, in our main set of results there was no change in monetary policy. Of course, monetary policy is a common factor across banks, so we do not think changes in policy will affect our cross-sectional analysis in either case.

For each of our deposit change results, we also report a parallel set of regressions for the week ending on October 26 (the week the spreads began to subside), and the three-week period 
ending on November 6, 1998. These weeks represent a resumption of normal conditions in the commercial paper market. Spreads began to fall after October 16, fell below 100 basis points by October 26, and fell below 60 basis points by November 4 . We also split the change in total deposits into the change in transactions deposits and the change in all other deposits to test whether these two kinds of products responded differently when liquidity demanded by the commercial paper issuers peaked. ${ }^{16}$ Each of these changes is normalized by the bank's total assets as of June 1998. ${ }^{17}$ As with the level of pre-existing transactions deposits, the data for deposit changes come from the Federal Reserve's FR2900 data.

C. Results

$\underline{\text { Summary Statistics }}$

Table 1 reports summary statistics for our dependent variables (Panel A) and for our explanatory variables (Panel B). Bank stocks clearly became significantly more volatile during the fall of 1998, rising from 0.02 daily standard deviation for the mean bank before the crisis (0.02 at the median) to 0.034 (0.032 at median) during the crisis. ${ }^{18}$ Moreover, bank deposit growth was much higher during the crisis weeks at the beginning of October than during the weeks at the end of the month. For example, the change in deposits relative to assets averaged 0.014 during the first week of October (crisis period), whereas deposits actually shrank by 0.004

\footnotetext{
${ }^{16}$ Transaction accounts is the sum of demand deposits, ATS accounts, NOW accounts/share drafts and telephone pre-authorized transfers.

${ }^{17}$ We considered looking at deposit growth, but this variable displays some extreme outliers (division by 0 or small number problem). Normalizing the change in deposits by total assets eliminates most of the outlier problems.

However, we also trim the deposit changes at the $1^{\text {st }}$ and $99^{\text {th }}$ percentiles in the regressions reported below. The results do not change materially for the crisis weeks if we do not trim, but the coefficient on deposit changes during the non-crisis period becomes much larger (as does its standard error) due to the influence of one observation.
} 
of assets during the week ending on October 26 (non-crisis period). Deposit growth during that first week of October annualizes to a change of about 70 percent of assets.

As noted, most of our explanatory variables come from the June 1998 Call Report to be sure that they are pre-determined with respect to the onset of crisis, with two exceptions. The transactions deposit ratio is taken from the August 10, 1998 FR2900 data, both to insure comparability with the deposit changes, and because we wanted to measure a bank's transaction deposit franchise as close to the onset of the crisis as possible. Our alternative measure of takedown demand is measured as the change in unused loan commitments during the second half of 1998.

As reported in Table 1, the typical bank held unused loan commitments equal to about 19 percent of its total credit exposure (on balance sheet loans plus unused commitments), and the amount of open lines increased by about 1.5 percent of exposures. The transactions deposit variable averaged 0.189 , and exhibited a wide range (from zero to 0.49 ). These are the two explanatory variables of greatest interest because they allow us to test the Kashyap et al. model, which implies that exposure to take-down risk on loan commitments can be partly hedged with transactions deposits. Means for the other controls variables are also reported in Table 1. Average bank size in the sample was $\$ 16.5$ billion (log of assets averaged 15.23). Two percent of the banks in the sample had exposure to Russia, and a little more than 1 percent ( 4 banks) of the banks had exposure to LTCM. Most of the banks are publicly traded ( 84 percent), but only one third have a credit rating (35 percent).

\footnotetext{
${ }^{18}$ These volatility figures are higher than the conditional volatilities plotted in Figure 1 because they include bankspecific idiosyncratic risk. The data in Figure 1 are based on an equally weighted index of bank stocks.
} 


\section{Bank Stock Return Volatility}

Table 2 reports the regression estimates for equation (1), where bank stock return volatility is the dependent variable. During the crisis period, there is a positive association between the unused loan commitments and volatility (statistically significant for the change in commitments), and a significant negative association between the size of a bank's transactions deposit ratio and volatility. That is, loan commitments seem to have exposed banks to risk, while transactions deposits helped them hedge that risk. ${ }^{19}$ The coefficient on the transaction deposits variable is especially striking. For example, a one standard deviation increase in this variable came with a decrease in stock return volatility of 0.004 , which about 40 percent of the crosssectional standard deviation in stock return volatility. Thus, during the crisis a bank with a large transaction deposit base experienced much lower return volatility because, as we will show below, it received a large inflow of new deposits.

Table 2 also shows that these relationships observed during the 1998 crisis do not reflect the normal links from liquidity exposure to risk. The coefficients on both loan commitments and transactions deposits in the volatility regressions are much smaller during the non-crisis period, and this difference is statistically significant at the five percent level. The effect of transactions deposits falls by a factor of about five, and the effect of loan commitments falls by a factor of

five to 10 (depending on the specification). Thus, the extent to which combining loan commitments with transactions deposits helps banks hedge risk is dramatically larger during the 1998 liquidity crisis than during normal times. This is consistent with our argument that the 
conditional correlation between liquidity demands of depositors and borrowers goes negative during liquidity crises - depositors put their money in banks just as borrowers draw money out. Or, said slightly differently, the diversification synergy of combining loan commitments and transactions deposits is especially powerful during crises.

Banks with LTCM exposure also had much higher stock return volatility than other banks during the crisis months. Sensibly, LTCM investments increased bank equity risk, both before and after the Russian default was announced. This result is consistent with Kho, Lee and Stulz (2000), who show that LTCM-exposed banks experienced a relatively large decline in stock prices compared to other banks when the hedge fund's problems first became public, and again when the coordinated restructuring occurred. ${ }^{20}$ Our results suggest that the market was aware of potential LTCM risk even before the news of the fund's difficulties became widely recognized (i.e. the coefficient is positive even during our pre-crisis period). This coefficient, of course, could be capturing more than just LTCM risk to the extent that these banks were engaged in other risk-enhancing activities such as proprietary trading.

Somewhat to our surprise, we find no effect on volatility of bank size or the other measures of liquidity risk (the fed funds purchased-to-assets or liquidity assets-to-assets ratios). We find that banks with more capital had higher, rather than lower, stock-return volatility. The small coefficient on bank size indicates that large banks were not viewed as relatively safer

\footnotetext{
${ }^{19}$ In principle, the opposite could also happen (when there is no government safety net in place). Transactions deposits could sometimes expose a bank to liquidity risk if consumers together remove deposits to increase consumption (e.g. the bank-run problem).

${ }^{20}$ The LTCM-exposed banks became equity holders in LTCM after the restructuring. Note that despite the higher equity risk for these banks, they were probably not close to insolvency. Furfine (2002) shows that LTCM-exposed banks continued to have access to borrowing in the unsecured Fed Funds market during this period.
} 
during the crisis, as might be expected if government safety nets become relatively more valuable for large banks at these times. These results are consistent with our deposit-flow evidence below, and with the findings of Gatev and Strahan (2003), who show that funds flowed into banks across the board, rather than to large (or well-capitalized) banks. ${ }^{21}$

\section{$\underline{\text { Bank Deposit Inflows }}$}

In Tables 3-6, we report estimates of the links from banks' transactions deposits base and their total unused loan commitments to deposit inflows during the crisis and recovery weeks of the commercial paper market. Table 3 focuses first on total deposit flows. During the first week of October, banks with more transactions deposits (as of the beginning of the crisis) experienced larger inflows of funds than other banks (columns 1 and 2). And, these funds seemed to have flowed out of banks as the CP market recovered during the week ending October 26 (columns 3 and 4). Three of these four coefficients are statistically significant at the 5 percent level, and all four are significant at the 10 percent level. Similarly, we find that banks with a higher level of pre-existing unused or open loan commitments had greater inflows during the crisis week, and greater levels of outflows during the recovery week. ${ }^{22}$ Banks with high levels of open credit lines thus seem to have experienced the greatest take-down demand as CP issuers turned to their banks for liquidity. This liquidity shock is reflected by deposits that were pulled into the bank by high loan demand. But, banks with higher levels of transactions deposits also experienced greater inflows. We interpret this latter inflow as a deposit-supply response to the crisis: when

\footnotetext{
${ }^{21}$ Gatev and Strahan (2003) use call report data to analyze the effects of CP spreads and loan commitments on balance sheet changes at quarterly frequency. Hence, they are not able to focus specifically on how deposit growth behaved during the critical weeks in October when take-down demand by commercial paper issuers spiked.
} 
investors lost their nerve, two things happened. First, the CP market dried up. Second, funds normally invested in commercial paper flowed temporarily into bank accounts. Thus, banks with high levels of both open commitments and transactions accounts experienced offsetting flows of funds.

Table 4 sharpens this result by looking specifically at the flows into bank transaction deposit accounts and into non-transaction deposit accounts separately. During the crisis week, the positive correlation between pre-existing transaction deposits and deposits flow shows up only in the transactions deposits accounts (Panel A). That is, banks with a large base of transactions deposit accounts experienced flows of fund into those accounts. In contrast, there is a negative correlation between the size of a bank's transactions deposit base and flows into nontransaction deposits. Also, there is no correlation between unused loan commitments and flows into transactions deposits.

The results in Table 4 validate our interpretation of unused loan commitments as controlling for shocks to loan demand (and hence bank demand for funds), whereas the size of the transactions deposit base control for shocks to deposit supply. The deposit-supply response to shocks at high frequency affects the transactions accounts, but demand shocks do not (hence the lack of correlation between unused lines and flows into transactions accounts). Banks probably can't fund high frequency demand shocks with transaction deposits unless they experience inflows into pre-existing accounts. Banks without these supplies of funds need to resort to other sources when take-downs increase unexpectedly. Hence, in columns 3 and 4 of

\footnotetext{
${ }^{22}$ The coefficient on the change in commitments is not statistically significant, however.
} 
Table 4 we estimate a positive and significant effect of unused loan commitments and growth in non-transactions deposits.

How do we know that banks are not paying higher interest rates for the funds that flow into transactions accounts? In Table 4, Panel B we disaggregate the transactions deposit change into the change in demand deposits versus the change in all other transaction accounts. These other accounts include such interest-bearing accounts as NOW accounts. Because banks pay no interest on demand deposit accounts, we can be sure that the flows into these accounts do not reflect an increase in a bank's willingness to pay for funds. That is, any change in these accounts (especially at high frequency like one week) must reflect shifts in deposit supply, rather than shifts in the bank's demand for funds. In fact, we find that all of the increased funding flows are concentrated in demand deposit accounts rather than other kinds of transactions deposit accounts.

Tables 5 and 6 report the same tests as in Tables 3 and 4, but now we expand the length of the crisis and non-crisis periods from one week to three weeks. We think this test is less powerful because the most dramatic changes in the $\mathrm{CP}$ market occurred rapidly. Nevertheless, we again find a positive correlation between banks' transaction deposit base and subsequent flows of deposit funds during the crisis weeks. As the crisis subsided at the end of October, the regression coefficient remains positive but loses statistical significance. That is, there is no statistically significant relationship between deposit flows and a bank's transaction deposit base as the commercial paper market recovered. (This result contrasts with the sign reversals observed at one-week frequency in Table 4.) Table 6 again shows that the funding inflows related to a banks pre-existing level of transactions deposits occurred into transactions accounts rather than non-transactions accounts. Overall, the results based on the three-week changes point 
in the same direction as the one week changes, but the differences between the crisis and noncrisis periods are somewhat muted.

\section{Conclusions}

This paper tests how bank risk and the supply of deposits reacted to the liquidity crisis of 1998. During this period, bank stock price volatility increased sharply in response to global shocks to credit markets. These shocks, which began when Russia defaulted, led to declining asset prices and widening spreads on risky debt across many markets in response to an investor 'flight to quality.' Spreads on safe securities such as U.S. government securities therefore fell sharply, while the supply of funds to banks increased. We show that this increase in funding supply was greatest at banks with large pre-existing transactions deposit accounts. This seems sensible to the extent that investors expected the market uncertainty to be relatively short in duration. We also show that banks with greater transactions deposit accounts had much lower stock return volatility than other banks.

Our results extend and deepen our understanding of the deposit-lending synergy suggested by Kashyap, Rajan and Stein (2002). According to their model, banks will combine liquidity provision to both depositors (through transactions deposits) and borrowers (through unused loan commitments) to reduce risk as long as liquidity demands from these two classes of customers are not highly correlated. The motivation for this combination is to diversify away some liquidity risk and thus reduce the need to hold cash. Our results suggest that this diversification effect becomes especially powerful during periods of crisis, when the correlation in demands for liquidity by depositors and by borrowers becomes negative. Depositors become 
net suppliers of liquidity during crises because they view banks as a safe haven, just as borrower demands for liquidity are at their highest. We find little relation between observable measures of bank safety such as size or rating and deposit flows. Thus, investors seem to view all banks as equally safe during liquidity crises (or at least during the 1998 crisis), presumably because of the presence of government safety nets and back-up liquidity from the central bank. 


\section{References}

Boyd, John and Mark Gertler, 1994, “Are Banks Dead? Or, Are the Reports Greatly Exaggerated?” Federal Reserve Bank of Minneapolis, Quarterly Review (Summer 1994), 1-19.

Chiodo, Abbigail and Michael T. Owyang, 2002, "A Case Study of a Currency Crisis: The Russian Default of 1998," St. Louis Federal Reserve Review, November/December, 7-17.

Diamond, Douglas and Philip Dybvig, 1983, "Bank Runs, Deposit Insurance, and Liquidity,” Journal of Political Economy 91(3), 401-419.

Edwards, Franklin, 1999, "Hedge Funds and the Collapse of Long-Term Capital Management," Journal of Economic Perspectives 13(2), 189-209.

Furfine, Craig, 2002, "The Costs and Benefits of Moral Suasion: Evidence from the Rescue of Long-Term Capital Management," Federal Reserve Bank of Chicago, Working Paper no. 200211.

Gatev, Evan and Philip E. Strahan, 2003, "Banks Advantage in Hedging Liquidity Risk: Theory and Evidence from the Commercial Paper Market," NBER working paper no. 9956.

Kane, Edward, 1974, "All for the Best: The Federal Reserve Board's $60^{\text {th }}$ Annual Report," American Economic Review, December, 835-850.

Kashyap, Anil K, Raghuram G. Rajan and Jeremy C. Stein, 2002, "Banks as Liquidity Providers: An Explanation for the Co-existence of Lending and Deposit-Taking," Journal of Finance 57(1), 33-74.

Kho, Bong-Chan, Dong Lee and René M. Stulz, 2000, "US Banks, Crises and Bailouts: From Mexico to LTCM," American Economic Review 90(2), 28-31.

Lowenstein, Roger, 2000, When Genius Failed: The Rise and Fall of Long-Term Capital Management, Random House (New York).

Mishkin, Frederic and Philip E. Strahan, "What will Technology do to Financial Structure?" 1998, in The Effect of Technology on the Financial Sector, Brookings-Wharton Papers on Financial Services, edited by Robert Litan and Anthony Santomero, 249-87.

Myers, Stewart C. and Raghuram G. Rajan, 1998, “The Paradox of Liquidity,” Quarterly Journal of Economics 113, 733-71. 
Nelson, Daniel, 1991, "Conditional Heteroskedasticity in Asset Returns: A New Approach," Econometrica 59, 247-70.

Saidenberg, Marc R. and Philip E. Strahan, 1999, “Are Banks Still Important for Financing Large Businesses?" 1999, Federal Reserve Bank of New York's Current Issues in Economics and Finance 5(12), 1-6.

Stiglitz, Joseph and Andrew Weiss 1981, "Credit Rationing in Markets with Imperfect Information" American Economic Review 71, (3), 393-410.

Uchitelle, Louis, 1998, "Sure Banks are Lending, but Will They Keep it Up?" New York Times, November 1, 1998. 


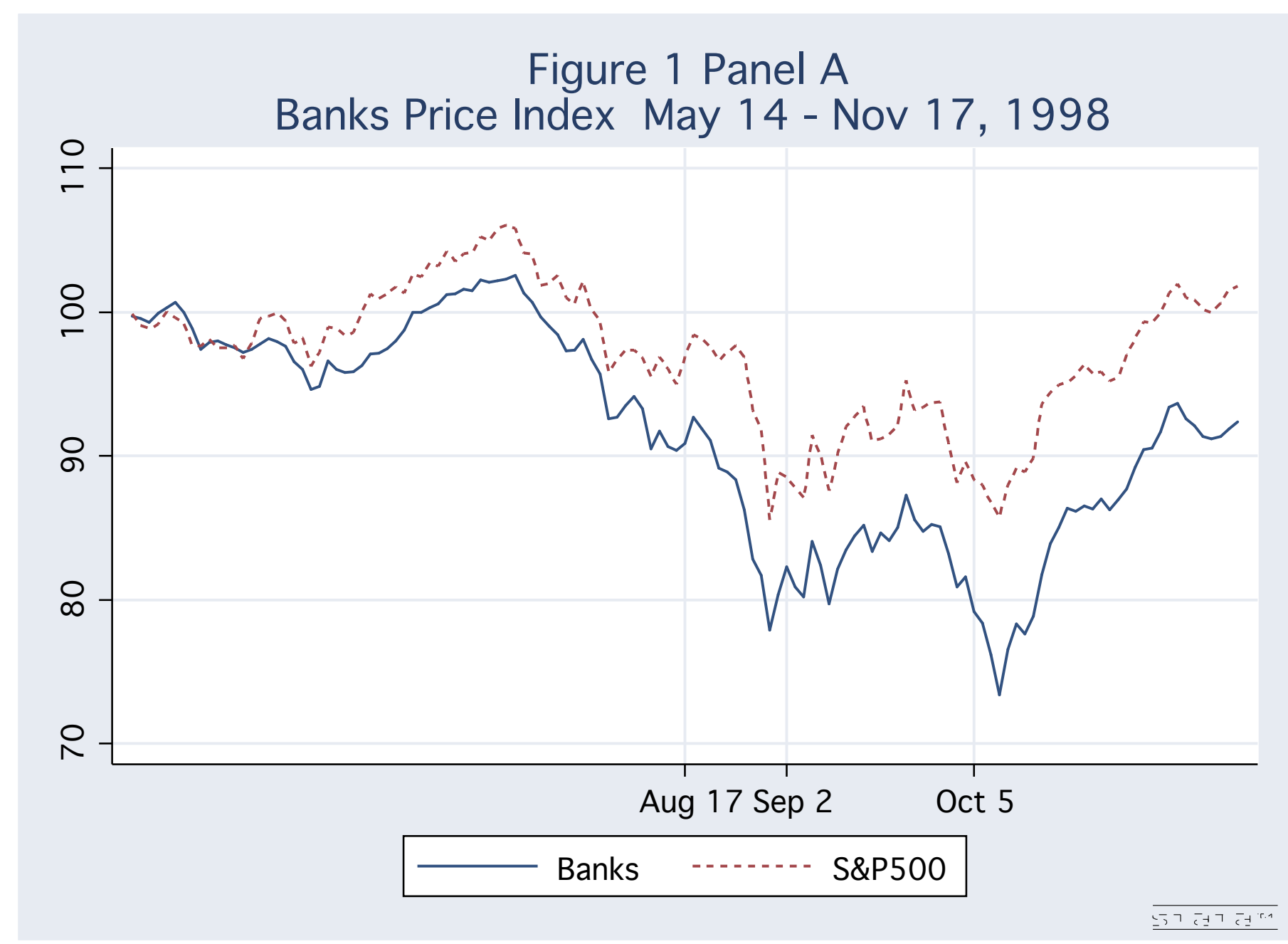




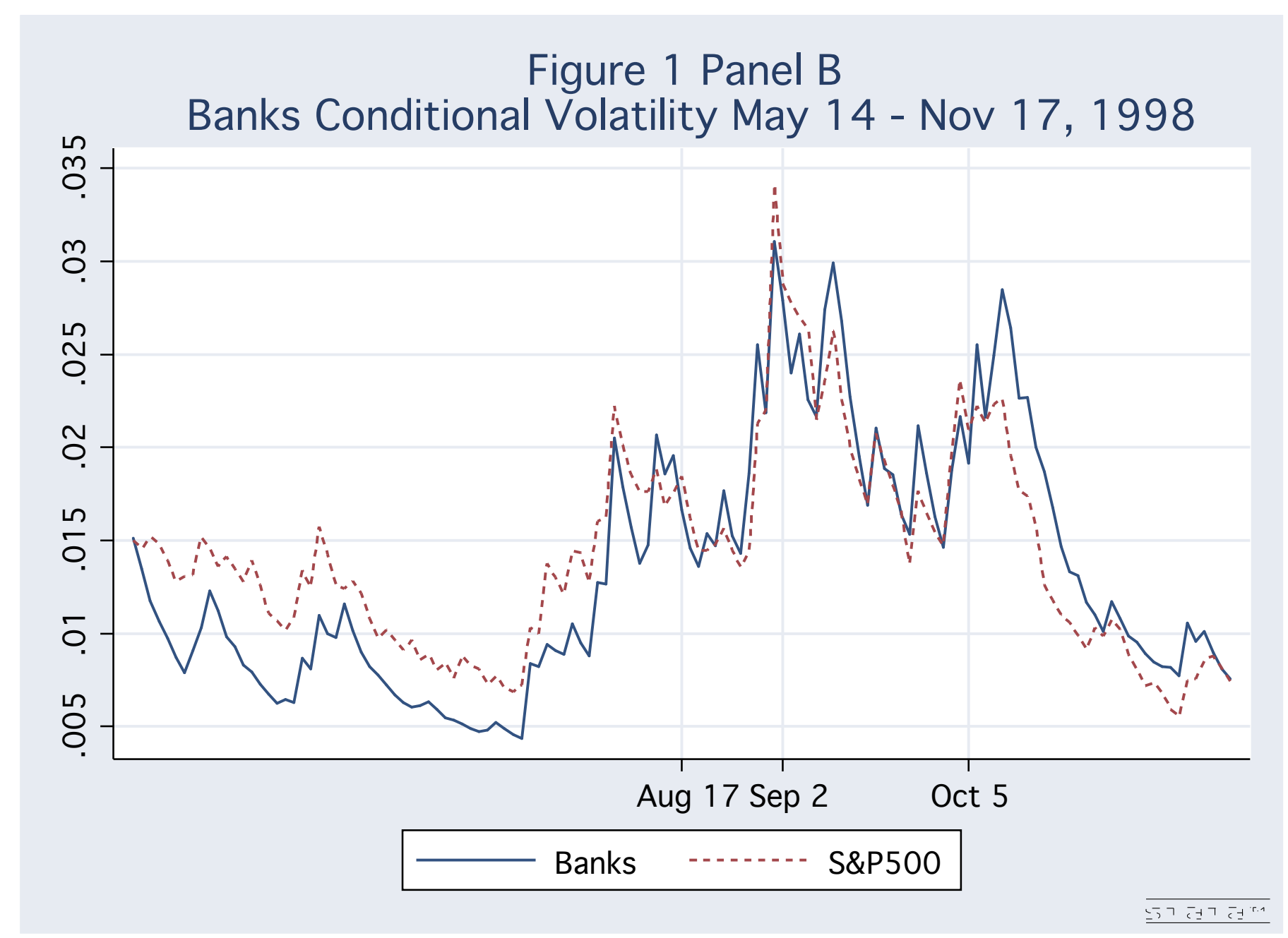




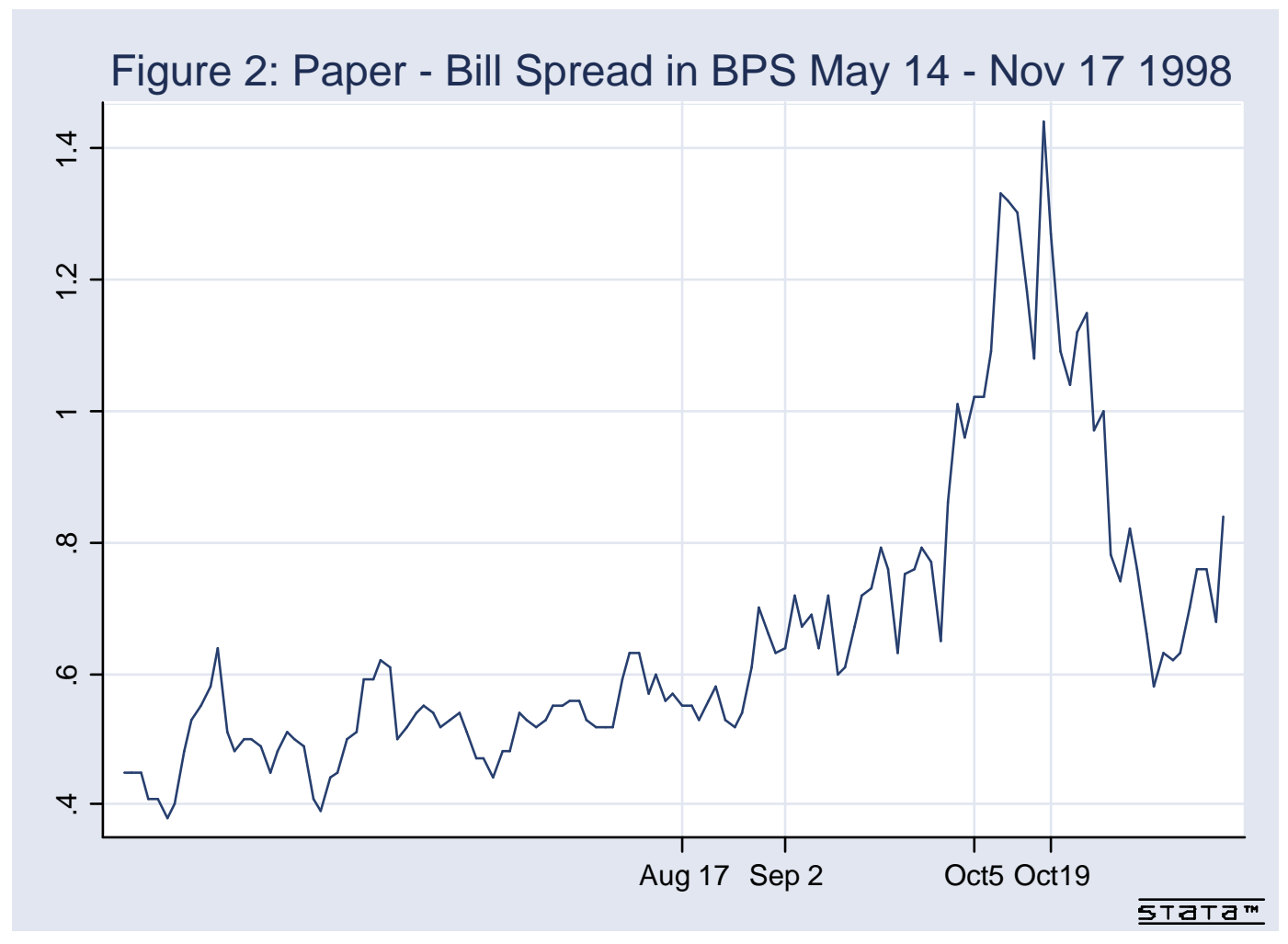




\begin{tabular}{|c|c|c|c|c|}
\hline \multicolumn{5}{|c|}{$\begin{array}{c}\text { Table } 1 \\
\text { Summary Statistics }\end{array}$} \\
\hline & \multicolumn{2}{|c|}{ Crisis-Period } & \multicolumn{2}{|c|}{ Non-Crisis Period } \\
\hline & & Standard & & Standard \\
\hline & Mean & Deviation & Mean & Deviation \\
\hline Panel A: Dependent Variables & $(1)$ & $(2)$ & (3) & (4) \\
\hline Stock Return Volatility & 0.034 & 0.011 & 0.020 & 0.006 \\
\hline Change in Total Deposits / Assets $6 / 98$ & 0.014 & 0.011 & -0.004 & 0.013 \\
\hline Change in Transactions Deposits / Assets $6 / 98$ & 0.004 & 0.009 & -0.002 & 0.008 \\
\hline \multirow[t]{4}{*}{ Change in Non-Transaction Deposits / Assets $_{6 / 98}$} & 0.011 & 0.015 & -0.003 & 0.012 \\
\hline & \multicolumn{2}{|c|}{$6 / 30 / 98$} & & \\
\hline & & Standard & & \\
\hline & Mean & Deviation & & \\
\hline Panel B: Explanatory Variables & & & - & - \\
\hline Transactions Deposits / Total Deposits & 0.189 & 0.100 & - & - \\
\hline Unused Commitments / (Commitments+Loans) & 0.187 & 0.127 & - & - \\
\hline$\Delta$ Unused Commitments / (Commitments+Loans) & 0.021 & 0.060 & - & - \\
\hline Log of Assets & 15.23 & 1.38 & - & - \\
\hline Russia Exposure Indicator & 0.022 & - & - & - \\
\hline LTCM Exposure Indicator & 0.013 & - & - & - \\
\hline Capital / Assets & 0.092 & 0.039 & - & - \\
\hline Fed Funds Purchased / Assets & 0.068 & 0.066 & - & - \\
\hline$($ Cash + Securities $) /$ Assets & 0.324 & 0.141 & - & - \\
\hline Has a Credit Rating Indicator & 0.349 & - & - & - \\
\hline Is Publicly Traded Indicator & 0.838 & - & & \\
\hline
\end{tabular}

Dependent variables: Stock return volatility equals the standard deviation of daily stock returns. The change in deposits are taken from the Federal Reserve's FR2900 data.

Explanatory Variables: With the exception of the transactions deposit ratio, explanatory variables are taken from the June 1998 Call Report. The transactions deposit / total deposits ratio is taken from the August 10, 1998 FR2900 data, as are the deposit growth rates (the dependent variables). Also, the change in commitments equals the difference in unused commitments in December 1998 minus unused commitments in June 1998

Crisis/Non-Crisis Periods: For stock return volatility, the crisis period begins on August 17, 1998 (when Russia defaulted) and ends three months later. The non-crisis period is the three month period ending on August 14, 1998. For deposit growth, the crisis week is the week ending on October 5, 1998 (the week that commercial paper spreads spiked); the non-crisis week is the week ending on October 26, 1998 (the week that commercial paper spreads began to subside). 


\section{Table 2}

Bank Liquidity Risk Declines with the Size of a Bank's Transactions Deposit Franchise

\begin{tabular}{|c|c|c|c|c|}
\hline & \multicolumn{2}{|c|}{$\begin{array}{l}\text { Crisis-Period Stock } \\
\text { Return Volatility: }\end{array}$} & \multicolumn{2}{|c|}{$\begin{array}{c}\text { Non-Crisis Stock Return } \\
\text { Volatility: }\end{array}$} \\
\hline & \multicolumn{2}{|c|}{$8 / 17 / 98-11 / 17 / 98$} & \multicolumn{2}{|c|}{$5 / 14 / 98-8 / 14 / 98$} \\
\hline & (1) & (2) & (3) & (4) \\
\hline \multirow[t]{2}{*}{ Transactions Deposits / Total Deposits } & $-0.037 *$ & $-0.041 *$ & -0.008 & $-0.009 *$ \\
\hline & $(0.011)$ & $(0.011)$ & $(0.004)$ & $(0.004)$ \\
\hline \multirow[t]{2}{*}{ Unused Commitments / (Commitments+Loans) } & 0.010 & - & 0.001 & - \\
\hline & $(0.011)$ & & $(0.004)$ & \\
\hline \multirow[t]{2}{*}{$\Delta$ Unused Commitments / (Commitments+Loans) } & - & $0.040^{*}$ & - & 0.010 \\
\hline & 0.001 & $\begin{array}{c}(0.018) \\
0.001\end{array}$ & -0.001 & $\begin{array}{l}(0.006) \\
-0.001\end{array}$ \\
\hline Log of Assets & $(0.001)$ & $(0.001)$ & $(0.001)$ & $(0.001)$ \\
\hline \multirow[t]{2}{*}{ Russia Exposure Indicator } & 0.003 & 0.005 & 0.001 & 0.001 \\
\hline & $(0.004)$ & $(0.003)$ & $(0.001)$ & $(0.001)$ \\
\hline \multirow[t]{2}{*}{ LTCM Exposure Indicator } & $0.017 *$ & $0.018^{*}$ & 0.011 & $0.012 *$ \\
\hline & $(0.006)$ & $(0.007)$ & $(0.006)$ & $(0.006)$ \\
\hline \multirow[t]{2}{*}{ Capital / Assets } & $0.039^{*}$ & $0.040^{*}$ & 0.003 & 0.004 \\
\hline & $(0.014)$ & $(0.016)$ & $(0.007)$ & $(0.007)$ \\
\hline \multirow[t]{2}{*}{ Fed Funds Purchased / Assets } & -0.001 & 0.003 & 0.010 & 0.011 \\
\hline & $(0.010)$ & $(0.015)$ & $(0.006)$ & $(0.006)$ \\
\hline \multirow[t]{2}{*}{ (Cash + Securities) / Assets } & 0.002 & -0.001 & -0.004 & -0.004 \\
\hline & $(0.007)$ & $(0.007)$ & $(0.004)$ & (0.004) \\
\hline \multirow[t]{2}{*}{ Has a Credit Rating Indicator } & -0.001 & -0.002 & -0.002 & -0.002 \\
\hline & $(0.002)$ & $(0.002)$ & $(0.001)$ & $(0.001)$ \\
\hline $\mathrm{N}$ & 175 & 175 & 178 & 178 \\
\hline $\mathrm{R}^{2}$ & 0.18 & 0.20 & 0.12 & 0.13 \\
\hline
\end{tabular}

Coefficients reported with robust standard errors in parentheses.

With the exception of the deposit ratio, explanatory variables are from the June 1998 Call Report. The transactions deposit / total deposits ratio is taken from the August 10, 1998 FR2900 data, as are the deposit growth rates (the dependent variables). Also, the change in commitments equals the difference in unused commitments in December 1998 minus unused commitments in June 1998.

*Indicates statistical significance at the 10 percent level. 
Table 3

Deposits Flow More into Banks with Larger Transactions Deposit Franchise

Transactions Deposits / Total Deposits

Unused Commitments / (Commitments+Loans)

$\Delta$ Unused Commitments / (Commitments+Loans)

Log of Assets

Russia Exposure Indicator

LTCM Exposure Indicator

Capital / Assets

Fed Funds Purchased / Assets

$($ Cash + Securities $) /$ Assets

Has a Credit Rating Indicator

Is Publicly Traded Indicator

$\mathrm{N}$

$\mathrm{R}^{2}$

Coefficients reported with robust standard errors in parentheses.

With the exception of the deposit ratio, explanatory variables are from the June 1998 Call Report. The transactions deposit / total deposits ratio is taken from the August 10, 1998 FR2900 data, as are the deposit growth rates (the dependent variables). Also, the change in commitments equals the difference in unused commitments in December 1998 minus unused commitments in June 1998.

The change in deposits is trimmed at the $1^{\text {st }}$ and $99^{\text {th }}$ percentiles.

*Indicates statistical significance at the 10 percent level. 


\section{Table 4}

Deposits Flow More into Banks with Larger Transactions Deposit Franchise Panel A: Transactions v. Non-transactions Deposit

\begin{tabular}{|c|c|c|c|c|}
\hline & \multicolumn{2}{|c|}{$\begin{array}{c}\text { Change in Transactions } \\
\text { Deposits / Assets } \\
6 / 98\end{array}$} & \multicolumn{2}{|c|}{$\begin{array}{c}\text { Change in Non- } \\
\text { transactions Deposits } \\
\text { Assets } \\
6 / 98\end{array}$} \\
\hline & \multicolumn{2}{|c|}{ 9/28/98-10/05/98 } & \multicolumn{2}{|c|}{ 9/28/98-10/05/98 } \\
\hline & (1) & (2) & (3) & (4) \\
\hline \multirow[t]{2}{*}{ Transactions Deposits / Total Deposits } & $0.044 *$ & $0.043 *$ & $-0.035^{*}$ & $-0.025 *$ \\
\hline & $(0.009)$ & $(0.007)$ & $(0.016)$ & $(0.013)$ \\
\hline \multirow[t]{2}{*}{ Unused Commitments / (Commitments+Loans) } & -0.009 & 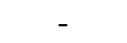 & $0.038^{*}$ & \\
\hline & $(0.006)$ & & $(0.015)$ & \\
\hline \multirow[t]{2}{*}{$\Delta$ Unused Commitments / (Commitments+Loans) } & - & -0.026 & - & $0.031 *$ \\
\hline & & $(0.014)$ & & $(0.016)$ \\
\hline \multirow[t]{2}{*}{ Log of Assets } & 0.001 & 0.001 & -0.001 & 0.001 \\
\hline & $(0.001)$ & $(0.001)$ & $(0.001)$ & $(0.001)$ \\
\hline \multirow[t]{2}{*}{ Russia Exposure Indicator } & -0.004 & $-0.005^{*}$ & -0.007 & -0.003 \\
\hline & $(0.003)$ & $(0.003)$ & $(0.004)$ & $(0.003)$ \\
\hline \multirow[t]{2}{*}{ LTCM Exposure Indicator } & 0.001 & -0.001 & -0.006 & $-0.005 *$ \\
\hline & $(0.003)$ & $(0.003)$ & $(0.006)$ & $(0.002)$ \\
\hline \multirow[t]{2}{*}{ Capital / Assets } & 0.009 & 0.010 & -0.046 & $-0.056 *$ \\
\hline & $(0.016)$ & $(0.016)$ & $(0.027)$ & $(0.029)$ \\
\hline \multirow[t]{2}{*}{ Fed Funds Purchased / Assets } & 0.009 & 0.007 & -0.010 & -0.007 \\
\hline & $(0.012)$ & $(0.011)$ & $(0.016)$ & $(0.017)$ \\
\hline \multirow[t]{2}{*}{ (Cash + Securities) / Assets } & -0.008 & -0.008 & 0.002 & 0.004 \\
\hline & $(0.005)$ & $(0.005)$ & $(0.008)$ & $(0.009)$ \\
\hline \multirow[t]{2}{*}{ Has a Credit Rating Indicator } & 0.002 & 0.002 & 0.001 & 0.001 \\
\hline & $(0.002)$ & $(0.002)$ & $(0.004)$ & $(0.004)$ \\
\hline \multirow[t]{2}{*}{ Is Publicly Traded Indicator } & $-0.003 *$ & $-0.003 *$ & 0.002 & 0.002 \\
\hline & $(0.001)$ & $(0.001)$ & $(0.002)$ & $(0.002)$ \\
\hline $\mathrm{N}$ & 222 & 222 & 223 & 223 \\
\hline $\mathrm{R}^{2}$ & 0.22 & 0.23 & 0.09 & 0.05 \\
\hline
\end{tabular}

Coefficients reported with robust standard errors in parentheses.

With the exception of the deposit ratio, explanatory variables are from the June 1998 Call Report. The transactions deposit / total deposits ratio is taken from the August 10, 1998 FR2900 data, as are the deposit growth rates (the dependent variables). Also, the change in commitments equals the difference in unused commitments in December 1998 minus unused commitments in June 1998.

The change in deposits is trimmed at the $1^{\text {st }}$ and $99^{\text {th }}$ percentiles. *Indicates statistical significance at the 10 percent level. 


\section{Table 4}

Deposits Flow More into Banks with Larger Transactions Deposit Franchise Panel B: Demand Deposits v. All Other Transactions Deposit

\begin{tabular}{|c|c|c|c|c|}
\hline & \multicolumn{2}{|c|}{$\begin{array}{l}\text { Change in Demand } \\
\text { Deposits / Assets } 6 / 98\end{array}$} & \multicolumn{2}{|c|}{$\begin{array}{c}\text { Change in Other } \\
\text { Transactions Deposits / } \\
\text { Assets }\end{array}$} \\
\hline & \multicolumn{2}{|c|}{ 9/28/98-10/05/98 } & \multicolumn{2}{|c|}{ 9/28/98-10/05/98 } \\
\hline & (1) & (2) & (3) & (4) \\
\hline \multirow[t]{2}{*}{ Transactions Deposits / Total Deposits } & $0.039 *$ & $0.040^{*}$ & 0.004 & 0.003 \\
\hline & $(0.007)$ & $(0.006)$ & $(0.004)$ & $(0.003)$ \\
\hline \multirow[t]{2}{*}{ Unused Commitments / (Commitments+Loans) } & -0.005 & - & -0.004 & - \\
\hline & $(0.006)$ & & $(0.003)$ & \\
\hline \multirow[t]{2}{*}{$\Delta$ Unused Commitments / (Commitments+Loans) } & - & $-0.024 *$ & - & -0.001 \\
\hline & & $(0.011)$ & & $(0.004)$ \\
\hline \multirow[t]{2}{*}{ Log of Assets } & 0.001 & 0.001 & 0.001 & 0.001 \\
\hline & $(0.001)$ & $(0.001)$ & $(0.001)$ & $(0.001)$ \\
\hline \multirow[t]{2}{*}{ Russia Exposure Indicator } & -0.004 & -0.004 & -0.001 & -0.001 \\
\hline & $(0.003)$ & $(0.003)$ & $(0.001)$ & $(0.001)$ \\
\hline \multirow[t]{2}{*}{ LTCM Exposure Indicator } & -0.001 & -0.001 & $0.001 *$ & $0.001 *$ \\
\hline & $(0.003)$ & $(0.003)$ & $(0.001)$ & $(0.001)$ \\
\hline \multirow[t]{2}{*}{ Capital / Assets } & 0.003 & 0.002 & 0.006 & 0.007 \\
\hline & $(0.012)$ & $(0.012)$ & $(0.007)$ & $(0.007)$ \\
\hline \multirow[t]{2}{*}{ Fed Funds Purchased / Assets } & 0.005 & 0.003 & 0.005 & 0.004 \\
\hline & $(0.010)$ & $(0.009)$ & $(0.005)$ & $(0.005)$ \\
\hline \multirow[t]{2}{*}{ (Cash + Securities) / Assets } & -0.004 & -0.005 & -0.003 & -0.004 \\
\hline & $(0.004)$ & $(0.004)$ & $(0.003)$ & $(0.003)$ \\
\hline \multirow[t]{2}{*}{ Has a Credit Rating Indicator } & 0.002 & 0.002 & 0.001 & 0.001 \\
\hline & $(0.001)$ & $(0.001)$ & $(0.001)$ & $(0.001)$ \\
\hline \multirow[t]{2}{*}{ Is Publicly Traded Indicator } & -0.002 & -0.002 & -0.001 & -0.001 \\
\hline & $(0.001)$ & $(0.001)$ & $(0.001)$ & $(0.001)$ \\
\hline $\mathrm{N}$ & 222 & 222 & 222 & 222 \\
\hline $\mathrm{R}^{2}$ & 0.24 & 0.27 & 0.03 & 0.03 \\
\hline
\end{tabular}

Coefficients reported with robust standard errors in parentheses.

With the exception of the deposit ratio, explanatory variables are from the June 1998 Call Report. The transactions deposit / total deposits ratio is taken from the August 10, 1998 FR2900 data, as are the deposit growth rates (the dependent variables). Also, the change in commitments equals the difference in unused commitments in December 1998 minus unused commitments in June 1998.

The change in deposits is trimmed at the $1^{\text {st }}$ and $99^{\text {th }}$ percentiles.

*Indicates statistical significance at the 10 percent level. 


\section{Table 5}

Deposits Flow More into Banks with Larger Transactions Deposit Franchise Three Week Changes

\begin{tabular}{|c|c|c|c|c|}
\hline & \multicolumn{2}{|c|}{$\begin{array}{c}\text { Crisis-Period Change in } \\
\text { Deposits / Assets }\end{array}$} & \multicolumn{2}{|c|}{$\begin{array}{l}\text { Non-Crisis Change in } \\
\text { Deposits / Assets } 6 / 98\end{array}$} \\
\hline & \multicolumn{2}{|c|}{ 9/28/98-10/19/98 } & \multicolumn{2}{|c|}{ 10/19/98-11/09/98 } \\
\hline & $(1)$ & (2) & (3) & (4) \\
\hline Transactions Deposits / Total Deposits & $0.036 *$ & $0.038^{*}$ & 0.058 & 0.044 \\
\hline & $(0.015)$ & $(0.015)$ & $(0.052)$ & $(0.048)$ \\
\hline Unused Commitments / (Commitments+Loans) & $\begin{array}{c}0.006 \\
(0.010)\end{array}$ & - & $\begin{array}{c}-0.012 \\
(0.016)\end{array}$ & - \\
\hline$\Delta$ Unused Commitments / (Commitments+Loans) & - & $\begin{array}{c}0.011 \\
(0.015)\end{array}$ & - & $\begin{array}{c}0.065 \\
(0.049)\end{array}$ \\
\hline Log of Assets & $\begin{array}{l}-0.001 \\
(0.001)\end{array}$ & $\begin{array}{l}-0.001 \\
(0.001)\end{array}$ & $\begin{array}{c}-0.005^{*} \\
(0.003)\end{array}$ & $\begin{array}{l}-0.006^{*} \\
(0.003)\end{array}$ \\
\hline Russia Exposure Indicator & $\begin{array}{c}0.063 \\
(0.048)\end{array}$ & $\begin{array}{c}0.064 \\
(0.047)\end{array}$ & $\begin{array}{l}-0.010 \\
(0.017)\end{array}$ & $\begin{array}{l}-0.011 \\
(0.016)\end{array}$ \\
\hline LTCM Exposure Indicator & $\begin{array}{l}-0.067 \\
(0.048)\end{array}$ & $\begin{array}{l}-0.067 \\
(0.048)\end{array}$ & $\begin{array}{c}0.019 \\
(0.017)\end{array}$ & $\begin{array}{c}0.021 \\
(0.017)\end{array}$ \\
\hline Capital / Assets & $\begin{array}{c}0.014 \\
(0.041)\end{array}$ & $\begin{array}{c}0.014 \\
(0.041)\end{array}$ & $\begin{array}{l}-0.025 \\
(0.097)\end{array}$ & $\begin{array}{l}-0.016 \\
(0.099)\end{array}$ \\
\hline Fed Funds Purchased / Assets & $\begin{array}{c}0.029 \\
(0.019)\end{array}$ & $\begin{array}{c}0.029 \\
(0.019)\end{array}$ & $\begin{array}{c}-0.040 \\
(0.030)\end{array}$ & $\begin{array}{l}-0.036 \\
(0.029)\end{array}$ \\
\hline (Cash + Securities) / Assets & $\begin{array}{l}-0.016^{*} \\
(0.010)\end{array}$ & $\begin{array}{c}-0.016^{*} \\
(0.010)\end{array}$ & $\begin{array}{l}-0.009 \\
(0.017)\end{array}$ & $\begin{array}{l}-0.014 \\
(0.016)\end{array}$ \\
\hline Has a Credit Rating Indicator & $\begin{array}{c}0.002 \\
(0.004)\end{array}$ & $\begin{array}{c}0.002 \\
(0.004)\end{array}$ & $\begin{array}{c}0.011 \\
(0.008)\end{array}$ & $\begin{array}{c}0.011 \\
(0.008)\end{array}$ \\
\hline Is Publicly Traded Indicator & $\begin{array}{c}-0.001 \\
(0.003)\end{array}$ & $\begin{array}{c}-0.001 \\
(0.003)\end{array}$ & $\begin{array}{c}-0.006 \\
(0.005)\end{array}$ & $\begin{array}{l}-0.007 \\
(0.005)\end{array}$ \\
\hline $\mathrm{N}$ & 223 & 223 & 222 & 222 \\
\hline $\mathrm{R}^{2}$ & 0.17 & 0.17 & 0.07 & 0.09 \\
\hline
\end{tabular}

Coefficients reported with robust standard errors in parentheses.

With the exception of the deposit ratio, explanatory variables are from the June 1998 Call Report. The transactions deposit / total deposits ratio is taken from the August 10, 1998 FR2900 data, as are the deposit growth rates (the dependent variables). Also, the change in commitments equals the difference in unused commitments in December 1998 minus unused commitments in June 1998.

The change in deposits is trimmed at the $1^{\text {st }}$ and $99^{\text {th }}$ percentiles.

*Indicates statistical significance at the 10 percent level. 
Table 6

Deposits Flow More into Banks with Larger Transactions Deposit Franchise Three Week Changes

Transactions v. Non-transactions Deposits

Transactions Deposits / Total Deposits

Unused Commitments / (Commitments+Loans)

$\Delta$ Unused Commitments / (Commitments+Loans)

Log of Assets

Russia Exposure Indicator

LTCM Exposure Indicator

Capital / Assets

Fed Funds Purchased / Assets

$($ Cash + Securities $) /$ Assets

Has a Credit Rating Indicator

Is Publicly Traded Indicator

$\mathrm{N}$

$\mathrm{R}^{2}$

Coefficients reported with robust standard errors in parentheses.

With the exception of the deposit ratio, explanatory variables are from the June 1998 Call Report. The transactions deposit / total deposits ratio is taken from the August 10, 1998 FR2900 data, as are the deposit growth rates (the dependent variables). Also, the change in commitments equals the difference in unused commitments in December 1998 minus unused commitments in June 1998.

The change in deposits is trimmed at the $1^{\text {st }}$ and $99^{\text {th }}$ percentiles.

*Indicates statistical significance at the 10 percent level.
Change in Nontransactions Deposits /

Assets $_{6 / 98}$ 9/28/98-10/19/98

$-0.012 \quad-0.003$

$(0.027) \quad(0.022)$

$(0.022)$

$\begin{array}{lll}-0.017 & - & 0.033\end{array}$

$(0.017) \quad(0.022)$

$\begin{array}{lll}-0.001 & -0.001 & 0.001\end{array}$

$\begin{array}{lll}(0.001) & (0.001) \quad(0.001)\end{array}$

$\begin{array}{llll}0.013 & 0.011 & 0.049 & 0.052\end{array}$

$\begin{array}{llll}(0.008) & (0.009) & (0.041) & (0.040)\end{array}$

$\begin{array}{lll}-0.013 & -0.057 & -0.056\end{array}$

$\begin{array}{llll}0.019 & 0.023 & -0.033 & -0.039\end{array}$

$\begin{array}{llll}(0.020) & (0.021) & (0.052) & (0.053)\end{array}$

$\begin{array}{llll}0.010 & 0.009 & -0.003 & -0.001\end{array}$

$\begin{array}{llll}(0.014) & (0.014) & (0.029) & (0.029)\end{array}$

$\begin{array}{cccc}-0.015^{*} & -0.016^{*} & 0.013 & 0.015\end{array}$

$\begin{array}{llll}-0.001 & 0.001 & -0.002 & -0.003\end{array}$

$\begin{array}{llll}(0.001) & (0.003) & (0.005) & (0.005)\end{array}$

$\begin{array}{llll}-0.003 & -0.003 & 0.004 & 0.004\end{array}$

$\begin{array}{llll}222 & 222 & 223 & 223\end{array}$

$\begin{array}{llll}0.18 & 0.16 & 0.08 & 0.07\end{array}$

